\title{
INVESTIGATION OF THE RELATIONSHIP BETWEEN KNOWLEDGE MANAGEMENT AND INNOVATION CAPABILITY: AN EMPIRICAL STUDY ON R\&D CENTERS IN EASTERN MARMARA REGION*
}

DOI: 10.17261/Pressacademia.2020.1327

RJBM- V.7-ISS.4-2020(10)-p.322-335

Selvi Gulyaz ${ }^{1}$, Alper Erturk ${ }^{2}$

${ }^{1}$ Duzce University, Institute of Social Sciences, Düzce, Turkey. selvigulyaz91@gmail.com, ORCID: 0000-0003-1073-3681

${ }^{2}$ Duzce University, Department of Management Information Systems, Duzce, Turkey. draerturk@gmail.com, ORCID: 0000-0002-8529-0806

Date Received: Novenber 1, 2020

Date Accepted: December 20, 2020

To cite this document

Gulyaz, S., Erturk, A. (2020). Investigation of the relationship between knowledge management and innovation capability: an empirical study on R\&D centers in Eastern Marmara Region. Research Journal of Business and Management (RJBM), V.7(4), p.322-335

Permanent link to this document: http://doi.org/10.17261/Pressacademia.2020.1327

Copyright: Published by PressAcademia and limited licensed re-use rights only.

\section{ABSTRACT}

Purpose - This study aims to explore the associations between knowledge management practices and innovation capability in R\&D centers that operate in Eastern Marmara Region, using an empirical research.

Methodology - Data were gathered using a web-based questionnaire from the senior managers of R\&D centers located and operating in Eastern Marmara Region. Total population sampling method was utilized and 120 managers were contacted. From those contacted, a total of 32 managers participated in our study. In order to test our hypotheses, multiple hierarchical regression analysis was used.

Findings- Findings of our analyses have shown that knowledge acquisition has a significant positive relationship with learning capability, production capability, marketing capability, and strategic planning capability. Moreover, results have also revealed a significant positive association between knowledge storing \& sharing and production capability, as well as between knowledge transformation and both marketing capability and organization capability.

Conclusion- We conclude that knowledge management is significantly and positively associated with innovation capability of R\&D centers. Specifically, knowledge acquisition and sharing have significant impact on learning, production, marketing and strategic planning components of innovation capability.

Keywords: Knowledge management, innovation capability, R\&D centers, innovation, Eastern Marmara Region JEL Codes: O31, O32, 034

\section{BiLGi YÖNETIMININ INOVASYON YETENEĞi iLE ILIŞKISININ INCELENMESI: DOĞU MARMARA BÖLGESINDEKI AR-GE MERKEZLERINDE BIR UYGULAMA}

\section{ÖZET}

Amaç - Bu çalışmanın amacı, Doğu Marmara bölgesinde faaliyet gösteren Ar-Ge merkezlerinde, bilgi yönetimi uygulamaları ile inovasyon yeteneği arasındaki ilşkinin, uygulamalı bir araştırma ile incelenmesidir.

Yöntem - Çalışmada kullanılan veriler, web-tabanlı bir anket kullanılarak, Doğu Marmara bölgesinde yer alan ve bu bölgede faaliyet gösteren ArGe merkezlerinin yöneticilerinden toplanmıştır. Örneklem yöntemi olarak tam sayım yöntemi kullanılmış ve bölgede bulunan 120 Ar-Ge merkezi yöneticisi ile iletişime geçilmiştir. İrtibat kurulan yöneticilerden sadece 32 yönetici çalışmaya dahil olmuş ve veri sağlamıştır. Elde edilen verilerin analiz edilmesi için çoklu hiyerarşik regresyon analizi kullanılmıştır.

Bulgular- Analizlerin neticesinde, bilginin elde edilmesi boyutunun, öğrenme yeteneği, üretim yeteneği, pazarlama yeteneği ve stratejik planlama yeteneği ile anlamlı pozitif ilişkisinin olduğu bulunmuştur. Ayrıca, sonuçlar, bilginin saklanması ve paylaşılmasının üretim yeteneği ile bilginin dönüştürülmesinin ise hem pazarlama hem de organizasyon yeteneği ile anlamlı ve pozitif ilişkisinin olduğunu ortaya koymuştur.

Sonuç- Bu çalışmada, bilgi yönetiminin Ar-Ge merkezlerinin inovasyon yeteneği ile olumlu ve anlamlı bir ilişkisinin olduğu ortaya konulmuştur. Özellikle bilginin elde edilmesi ve paylaşılmasının, inovasyon yeteneğinin öğrenme, üretim, pazarlama ve stratejik planlama boyutları açısından önemli olduğu sonucuna varılmıştır.

Anahtar Kelimler: Bilgi yönetimi, inovasyon yeteneği, Ar-Ge merkezleri, inovasyon, Doğu Marmara Bölgesi JEL Kodları: O31, O32, O34

* Bu makale, Prof. Dr. Alper Ertürk'ün danışmanlığında, Selvi Gülyaz tarafından yazılan “Bilgi Yönetiminin İnovasyon Yeteneği ile İlişkisinin Incelenmesi: Doğu Marmara Bölgesindeki Ar-Ge Merkezlerinde Bir Uygulama" başlıklı yüksek lisans tezinden üretilmiştir. 


\section{Giriş}

Günümüzün hızla değişen piyasa şartlarında ve yüksek rekabet koşullarında hayatta kalmaya çalışan işletmeler sürekli olarak yenilik arayışına girmekte ve pazarda daha fazla tutunmak için farklılık oluşturmayı bir strateji olarak belirlemektedirler. Bu strateji içerisinde inovasyon yeteneği önemli bir rol oynamaktadır. İnovasyon yetenekleri sayesinde, firmalar süreç ve ürünlerinde yenilikçi uygulamalar ortaya koyabilmekte ve bu sayede öğrenmeye açık ve dinamik bir yapıda başarılarını sürdürme şansı yakalamaktadırlar (Calantone vd. 2002).

Firmaların etkinliği va başarısı üzerinde bu denli etkisi olan inovasyon yeteneğini elde etmek ve geliştirmek için önemli kurumların başında ise Ar-Ge (Araştırma-Geliştirme) merkezleri gelmektedir. Ar-Ge merkezleri, organizasyonlarda teknolojik bilgi üretmek, üründe ve üretim süreçlerinde yenilik yapmak, ürün kalitesi ve standardının yükseltilmesini sağlamak, verimliliğin artırılması ve üretim maliyetlerinin düşürülmesini mümkün kılmak amacıyla, tasarım, ürün ve süreçleri araştırmak ve geliştirmek üzerine faaliyet göstermektedirler. Bu çerçevede, Ar-Ge merkezleri sağladıkları inovasyon yeteneği ile firmaların ulusal ve uluslararası pazarlarda sürdürülebilir rekabetçilik elde etmesine büyük katkı sağlamaktadır.

Dolayısıyla, hemen her alanda ve sektörde faaliyet gösteren işletmeler, böylesine önemli bir yeteneği elde etmek ve kullanabilmek amacıyla Ar-Ge merkezleri kurma yoluna gitmektedirler. Firmalar adına kurulan Ar-Ge merkezleri sağladıkları teknolojik hizmetlerle, farklı ve yeni olanı üretebilmek için, daha da önemlisi inovasyon yeteneğinin kullanılabilmesinde tetikleyici bir faktör olarak görülmektedir (Colombo \& Garrone, 1996).

Ar-Ge merkezleri, özellikle firmaların inovasyon yeteneklerinin arttırılmasında ve etkin kullanılmasında bu denli önemli olmasına rağmen, ülkemizde bölgesel anlamda Ar-Ge merkezlerinin çalışmalarına ve inovasyon yeteneklerinin arttırılmasına yönelik akademik araştırmaların sınırlı kaldığı görülmektedir. Biz bu çalışmamızda, bu açığı kapatabilmek ve bilgi yönetimi ile inovasyon yeteneği arasındaki ilişkiyi uygulamalı bir çalışmayla pekiştirmek adına, Doğu Marmara bölgesinde faaliyet göstermekte olan ArGe merkezlerini konu aldık ve bu merkezlerin inovasyon yeteneklerinin geliştirilmesinde bilgi yönetiminin etkisinin ne olabileceği konusunu araştırdık.

Doğu Marmara Bölgesinin ulaşım ağlarının geniş yelpazede yer alması, Düzce, Bolu, Sakarya, Kocaeli ve Yalova bölgelerinin bilim, sanayi, teknoloji, teknopark, üniversitelerin bilimsel araştırmalara destek olması, değişim, gelişim, kalkınma ve büyümenin ekonomide etkili olması, bu bölgede Ar-Ge merkezlerinin yaygınlaşmaya başlamasında etkili olmaktadır. Türkiye îhracatçılar Meclisi tarafından her yıl açıklanan "Türkiye'nin ilk 1000 ihracatçısı" listesinde hem sayı hem de sıralamalarda yer alan şirketlerin birçoğunun Doğu Marmara bölgesinde yer alan şirketler olması da, bu bölgenin kalkınma ve sürdürülebilirlik anlamında ülkemizin lokomotifi konumunda olduğunun bir başka göstergesi olarak ortaya çıkmaktadır. Bu nedenle, yaptığımız bu çalışmada, hem sanayii hem de ticaret anlamında önemi ve etkisi giderek artan bu bölgeyi ele alarak, bölgenin önemini daha da pekiştirecek olan, inovasyon yeteneğinin artmasını sağlayacak Ar-Ge merkezlerinin bölgedeki etkinliğinin belirlenmesine fayda sağlayacak bir konuyu araştırdık. Günümüzde özellikle de bilgi ve iletişim teknolojilerinin de gelişmesi ve yaygınlaşmasıyla birlikte, veri ve bilgi her alanda hızlı bir şekilde artmaya devam etmektedir. Önemli olan konu ise, bu veri ve bilginin doğru ve güvenilir bir şekilde kullanılmasıdır. Tüm bu amaçlar çerçevesinde, araştırmamızda spesifik olarak, Doğu Marmara bölgesinde faaliyet göstermekte olan Ar-Ge merkezleri özelinde, bilgi yönetiminin inovasyon yeteneği ile ilişkisi ortaya konulmaya çalışılmıştır.

Bu çalışmada, öncelikle yapılan literatür taraması çerçevesinde, inovasyon, inovasyon yeteneği ve bilgi yönetiminin tanımları yapılacak, daha sonra bilgi yönetimi ve inovasyon yeteneği arasındaki ilişkiyi destekleyen çalışmalar ve teoriler özetlenecektir. Daha sonra çalışmada izlenen metodoloji özetlenerek, toplanan verilerin analiz edilmesinden elde edilen bulgular tablolarla desteklenerek özetlenecektir. Çalışmanın son bölümünde, elde edilen sonuçlar ve değerlendirmeler ile, gelecekte yapılacak çalışmalar için önerilen hususlar yer alacaktır.

\section{INOVASYON}

İnovasyon tanımı için Elçi (2007); “inovasyon” kelimesinin "Latince” olduğunu açıklamakta ve "inovasyon” kelimesinin köklerinin "innovatus" sözcüklerinden zamanla meydana geldiğini ifade etmektedir. Aynı zamanda inovasyon için "Toplumsal, kültürel ve idari ortamda yeni yöntemlerin kullanılmaya başlanması" şeklinde ifade ederek tanımlamıştır (Elçi, 2007). İnovasyon tanımı birçok kaynakta farklı şekilde açıklanmaya çalışılsa dahi tam olarak bir karşııı̆ının olmadığı sonucuna varılmaktadır. Her ne kadar inovasyon tanımı zor olsa bile inovasyon; yeni ve yenilik anlamını taşıyan, ilk ve daha önce olmamış bir üretimin gerçekleştirilmesi olarak tanımlanabilmektedir (Tidd vd., 2005).

Sanayileşmenin başlaması dünya genelinde küreselleşmenin hızlı bir şekilde hissedilmesine sebep olmuştur. Sanayileşmeyle birlikte teknoloji de hızlı bir biçimde gelişerek ithalat, ihracat, ticaret, pazarlama-satış alanlarında rekabet ortamını oluşmuştur. Yoğun rekabet ortamının hızlanması da, üretim alanında çeşitliliği gerekli kılmış ve hep daha yeni olanın arayışına başlanmıştır. Yeni olan sadece üretim demek değil, farklı üretimi tetikleyecek olan farklı düşünce sistemini ve inovasyonun gelişmesinde öncülük oluşturan fikirleri de kapsamaktadır. Ticaretin gelişmesine inovasyonun yoğun rekabet ortamında gün geçtikçe değeri anlaşılmış 
ve gittikçe önemi artmaya devam etmektedir. Kurum ya da kuruluşlar rekabet ortamında pazarda büyümek için inovasyonu aracı olarak görmüşlerdir. Daha iyi ve daha kaliteli ürünler pazara sunarak piyasadan daha yüksek kar elde etmenin planlarını araştırmışlardır (Maravelakis vd., 2006). Firmalar farklı stratejiler uygulayarak rakipleri arasında farklılık oluşturabilmek için inovasyondan yararlanmaya başlamışlardır. İnovasyonun hemen her alana uygulanabilir olması da bu farkı oluşturmakta öncelik elde etmesini sağlamıştır (Vila \& Kuster, 2007).

Inovasyonun üzerine odaklanan firmalar çeşitli planlamalar yaparak hem inovasyonu geliştirmeye odaklanmış hem de yatırım yaptıkları araştırma merkezlerine yönelerek yeni inovasyon modelleri oluşturmaya çalışmışlardır (Ishak vd., 2013). Bu yönüyle inovasyon, sadece bir yaklaşım olmaktan çıkmış, bir yönetim fonksiyonu haline gelmiştir. Firmaların yönetim kademelerinde, lojistik tedarik, üretim, pazarlama, satış, insan kaynakları, finans, muhasebe, bilgi teknolojisi gibi hemen her alanda uygulanabilmekte ve tüm alanlarda verimliliği arttırmaktadır (Rosenbusch vd., 2011).

İnovasyonun, firmalar üzerindeki etkisi firmanın küçüklüğüne ve büyüklüğüne göre de değişmekle birlikte, tüm işletmeler üzerinde olumlu katkısı bulunmaktadır. Küçük firmaların hedef kitlesi belirli bölgedeki insanları kapsarken büyük firmalar geniş alanlarda faaliyet göstermektedir. Faaliyet gösterdikleri bölgelerde uzun vadede piyasada tutunması için firmanın yaşı, büyüklüğü, hedef kitlesi, tolumun kültürel yapısı da etkili olmaktadır. Firmalar için bu özellikler inovasyonun uygulama alanlarını da etkilemektedir. İnovasyonu kullanan firmalar bu özellikleri dikkatli uygulayarak verim alabilmektedir (Rosenbusch vd., 2011).

\section{BiLGi YÖNETIMI}

Bilgi kavramı, bilgi yönetiminin uygulanmasında gerekli olan değerlerin, fikirlerin anlamlandırılarak bilgi yönetiminin gerçekleştirilmesinde aracı olan kişinin deneyimleri olarak tanımlanmaktadır (Rubenstein-Montano vd., 2001). Bilgi, insanların edindiği ve kullandığı verileri ifade edebilmesidir (Grant, 1996). Bilgi, problemlerin çözülmesinde etkili olan araçların aynı zamanda da kaynaklarla ifade edilebilmesi olarak tanımlanmaktadır (Gupta vd., 2000). Bilgi yönetimi ise, amaç ve hedeflerini gerçekleştirebilmeleri amacıyla, gereken donanım ve verilerin değerlendirilerek uygulama aşamasına geçebilmek için tüm gerekli alt yapının hazırlanması, ihtiyaç duyulan verilerin elde edilerek kontrol mekanizmasının kurularak bu sürecin takibi, başka bir ifadeye göre ise, devamlılığının sürdürülmesi "yürütülmesi", biçiminde açıklanabilmektedir (Lee \& Suh, 2003). Bilgi yönetimi, bilgilerin işlenmesinde organize olabilmeyi gerekli kılan, güçlü iletişim bağlarının kurulması, insan kaynaklarının temin edilmesi, finansal ihtiyaçların belirlenmesi, belirlenen bu ihtiyaçların temin edilerek kullanılabilir hale gelmesinde etkin olan süreçlerin sürdürülebilmesi olarak da tanımlanabilmektedir (Fugate vd., 2009).

Bilgi yönetimi, firma yöneticileri, çalışanlar ve müşteriler arasında istek ve beklentilerin değerlendirilmesini, elde edilen bilginin kullanılarak farklı boyutlara dönüştürülmesini, aynı zamanda elde edilen verilerin firma açısından faydalı olması için paylaşılmasını gerekli kılan yapının oluşturulması, yönetilmesi ve yürütülmesi de sağlamaktadır (Gupta vd., 2000). Bilgi yönetimi kapsamında işletmeler gerçekleştirmek istedikleri uzun vadeli hedefler doğrultusunda, stratejik olarak hedeflenen uzun ve kısa vadeli planlar dahillinde firmanın faaliyetlerini sürdürülebilir kılması için de önemli bir altyapı ve imkan sağlamaktadır (Biloslavo vd., 2018).

Firmaların inovasyon yetenekleri, yukarıda açıklandığı üzere, ekonomik büyüme ve gelişmeye yönelik itici gücü oluşturmaktadır. Firmaların bu öncemli gücü kullanabilmeleri için gerekli olan en önemli kaynak ise bilgi ve bu bilginin etkin yönetilmesidir. Bunu gerçekleştiremeyen firmaların yenilikçi olmaya çalışmalarına ve yenilik yeteneklerini kapasiteleri dahilinde kullanmalarına rağmen, inovasyon yeteneklerinin performanslarına istenen düzeyde etkisinin olmadığı tespit edilmiştir (Korkmaz vd., 2009).

Firmaların yeni bilgiyi yakalaması, değerlendirmesi ve doğru kullanabilmesi inovasyon yeteneğinin gelişmesini sağlamıştır. Firmaların yenilik yapma istekleri mevcut bilgiyi kullanmalarını ve yeni bilgiyi elde etmek için yeteneklerini kullanmalarını gerekli kılmaktadır. Ar-Ge yeteneği, doğru bilgiyi elde etmeyi ve bu bilgiyi doğru şekilde kullanmayı hedefleyen firmalar için çok önemli bir araç ve altyapı sunmaktadır. Narasimhan vd. (2006)'ne göre, Ar-Ge yeteneğini kullanan firmaların inovasyon yetenekleri ve dolaylı olarak "karlılık" oranlarında artış olduğu tespit edilmiş ve ayrıca karlılık oranlarının "teknolojik değişim" hızıyla ilişkisinin olduğu vurgulanmıştır.

\section{BILGI YÖNETIMI VE INOVASYON YETENEĞi}

Bilgi yönetimi, inovasyon yeteneği ve işletmenin finansal ve finansal olmayan başarısı arasındaki ilişki birçok çalışmada ele alınmış ve farklı şekillerde ortaya konulmuştur. Bu çalışmalar, bilgi yönetiminin ve süreçlerinin doğru tasarlandığı ve etkin kullanıldığında, inovasyon yeteneğinin daha etkili hale getirilmesi için fırsatlar sunduğunu, bu yeteneğin de işletmelerin başarısına doğrudan ve kuvvetli bir etki yaptığını açık şekilde ortaya koymaktadır.

Lane vd. (2006), bilginin yönetimi sürecinin, özellikle de bilginin dönüştürülmesi sürecinin etkin ve doğru işletilmesi gerektiği, bu sürecin zaman başta olmak üzere birçok anlamda farklılık yarattığı, çalışanların motivasyonuna dahi olumlu veya olumsuz etki yaptığı, bu nedenle de organizasyonel başarının sağlanması için "özenli, titiz ve sorgulayıcı" olunması gerektiğine dikkat çekmektedir. Böylece yapılacak çalışmaların "geçerli ve kullanışlı” olabileceği konusuna vurgu yapmışlardır. Todorova ve Durisin 
(2007) ise, bilgi yönetimi alt boyutlarından bilginin korunması ve işletme içerisinde etkin paylaşılmasının inovasyon yönetimi alt boyutlarından öğrenme ve Ar-Ge yeteneği üzerindeki etkilerine dikkat çekmiş, rekabetin yüksek olduğu pazarlarda Ar-Ge yeteneğinin firma performansını olumlu yönde etkilediğini göstermişlerdir. Bu süreç içerisinde, bilginin korunmasının ise elde edilecek olan verilerin farklılaşmasını sağladığı böylece fimanın pazarda değerinin artmasına katkıda bulunduğu gösterilmiştir (Todorova \& Durisin, 2007).

Zahra ve George (2002)'a göre, bilginin uygulanabilir olması, firmalarda güven ortamının oluşmasına ve böylece süreçleri olumsuz etkilemeden yeni bilgiler edinerek öğrenme yeteneğinin geliştirilmesine katkı sağlamaktadır. Flatten vd. (2011) göre ise, kaynak tahsisi yeteneğinin sağlanması firmalarda bilginin elde edilmesini ve firmanın daha ileri düzeyde başarı göstermesi adına firmayı bir adım ileri taşıyarak firmanın büyümesi ve gelişmesine katkıda bulunmaktadır. Kostopoulos vd. (2011)'e göre ise, firmalar kaynak tahsisi yeteneği ile yeni veriler elde ederek bilgiyi dönüştürmekte ve kapasitelerini genişleterek üretim yeteneklerini geliştirmektedirler. Kaynak tahsis yeteneği inovasyonun değer kazanmasını ve böylece finansal değerlerin artmasına avantaj oluşturmaktadır.

Wang ve Han (2011)'a göre, bilginin uygulanabilir olmasının, inovasyon yeteneğinin performansını doğrudan arttırdığını göstermektedir. Teknolojinin de yardımıyla bilgiyi etkin bir şekilde işleyen ve kullanan firmaların, kaynak tahsis yeteneğinden üretim yeteneklerine kadar inovasyon yeteneklerinde önemli bir artış meydana gelmektedir. Camison ve Fores (2010)'a göre, küresel rekabet ortamında firmaların rekabet etme gücünün artması ve bu rekabetçiliklerinin sürdürülebilir olması, bilgi yönetimi ve inovasyon yeteneklerini doğru ve etkin kullanılması ile doğru orantılıdır. Nemanich vd. (2010)'e göre ise, bilgi yönetimi, yetenekli iş gücünün ortaya çıkmasına da katkıda bulunmakta, böylece ekonomik faydaya dönüşmesine fırsat sunmaktadır.

Hsu ve Fang (2009)'a göre, üretim yeteneğinin uygulanabilir bilgi sunması, sürekli yeniliği artırmakta ve fayda oluşturmaktadır. Böylece yeni ürün geliştirme stratejileri teşvik edilerek, pazarda firmaların rekabetçiliklerinin sürdürülebilirliğine katkı sağlanmış olmaktadır. Çalışmalar ayrıca, inovasyon yeteneğinin firmalara pazara farklı giriş yolları açtığını, farklı pazarlama yöntemleri kullanılmasına fırsat verdiğini, böylece mevcut rakiplere karşı yeni firmaların pazarda tutunmasını sağlamaya yönelik avantaj oluşturduğunu ortaya koymaktadır (Jansen vd., 2005; Narasimhan vd., 2006).

Knockaert vd. (2014)'e göre, bilgi yönetiminden ve teknoloji destekli inovasyon yeteneğinden etkin bir şekilde faydalanmak, uygulanabilir sonuçlar ortaya sunulmasına ve dolaylı olarak firma kapasitesinin artmasına neden olmaktadır. İnovasyon yeteneğinin önemli alt boyutlarından olan organizasyon yeteneği, inovasyon için gerekli olan süreçte bilgi edinimini kolaylaştırarak, firmaların stratejik planlarının gerçekleştirilmesine katkı sağlamaktadır (Li, 2011). Hervas-Oliver vd. (2011) tarafından gerçekleştirilen bir başka çalışmada da, organizasyon yeteneğinin müşteri beklentilerini karşılamak adına uygun fiyat avantajları sağlayan ürünlerin piyasa sürülmesine ve pazarlanmasına katkı sağladığı, böylece pazardaki beklentileri karşılayabilecek inovasyon modelleri oluşturulmasının mümkün olduğu öne sürülmektedir. Rothaermel ve Alexandre (2009) göre de, organizasyon yeteneğinin kullanılarak bilginin doğru alanlarda etkin olarak kullanılması, müşteri ve firma belirsizliklerini ortadan kaldırmaktadır. Lau ve Lo (2015)'e göre, bilgi edinimi sürecinin doğru işletilmesiyle, stratejik planlama yeteneği geliştirilmekte, bu da satış ve pazarlama stratejilerine doğrudan katkı sağlamaktadır. Nemanich vd. (2010)'e göre ise, stratejik planlama yeteneği ile üretim teknolojisinin iyileştirilmesi doğrudan ilişkilidir. Ayrıca yeni pazar payını artırmak, kritik kaynaklardan önemli bilgiyi elde ederek dönüştürmek ve böylece stratejik planlama yeteneğini artırmakla mümkün olabilmektedir. Bu stratejik plnlama yeteneği, firmaların pazarda büyüyerek rakiplerine karşı rekabetçi konumunu sağlamlaştırmasına yardımcı olmaktadır.

Yam vd. (2011)'ne göre, stratejik planlama yeteneği ile firmalar finansal ve finansal olmayan performanslarını artırabilmektedirler. Mevcut kaynakları doğru kullanıp ve yeni kaynaklar üretip kullanarak, pazarda zaman ve maliyet açısından üstünlük sağlayıp karlılıklarını artırabilmektedirler. Xia ve Roper (2008)' e göre ise, stratejik planlama yeteneği ile ürün kalitesi artırılmakta ve müşteri istekleri kaliteli bir biçimde karşılanmaktadır. Kalite stratejik planlama yeteneği kullanan firmalarda ön plana çıkmaktadır.

Tüm bu araştırmaların ışığında, bilgi yönetiminin ve bilgi yönetimi alt boyutlarının, firmaların inovasyon yeteneklerine olumlu ve anlamlı katkı yaptığı öne sürülebilir. Biz de yaptığımız uygulamalı çalışmayla, bu ilişkiyi ampirik olarak göstermeye çalıştık.

\section{ARAŞTIRMANIN YÖNTEMI}

Bu araştırmanın veri toplama süreci Doğu Marmara Bölgesini kapsamaktadır. Araştırma kapsamı firmaların Ar-Ge Merkezleri olmaktadır. Bu araştırma için soru formunu dolduracak firmaları belirlemek ve iletişim kurmak amacıyla, T.C. Bilim Sanayi ve Teknoloji Bakanlığı'na bağlı Ar-Ge Merkezleri veri tabanından faydalanılarak Doğu Marmara Bölgesinde faaliyet gösteren Ar-Ge merkezlerinin listesine ulaşılmıştır. Ulaşılan Ar-Ge Merkezleri yöneticilerine araştırmamıza katılım için davetiye gönderilmiştir.

Veri toplam süreci 17 Temmuz-21 Ekim 2018 tarihleri arasında gerçekleşmiştir. Veri toplam süreci Doğu Marmara Bölgesindeki 120 Ar-Ge merkezi belirlenerek listenmiştir. Veri toplama yönteminin seçilmesinde e-mail tercih edilmiş ve kullanılmıştır. Araştırmaya katılım tamamen gönüllülük esasına göre gerçekleştirilmiş olup, katılımcılar veya firmalarla ilgili olarak herhangi bir açık kimlik bilgisi istenmemiş, çalışma anonim olarak gerçekleştirilmiştir. Çalışmada elde edilecek verilerin sadece bu çalışma 
kapsamında kullanılacağı ve herhangi üçüncü kişi veya kurumlarla paylaşılmayacağına dair katılımcılara taahhüt verilmiştir. Araştırma örneklemi için Doğu Marmara Bölgesi'ndeki Ar-Ge Merkezlerine gönderilen e-mailler, soru formunu dolduracak olan firmaların Ar-Ge Merkezi yöneticilerinin kendi e-mail adresine gönderilmiştir. Bunun haricinde tek tek firmalar gezilip anket yapılmıştır. Araştırma süreci 21 Ekim tarihinde sonlandırılmıştır. Tüm bu çalışmalar sonucunda toplamda 32 yöneticiden veri toplanmış ve analize dahil edilmiştir.

Araştırma kapsamında geçerlilik ve güvenilirliği literatürde kanıtlanmış ölçekler kullanılmıştır. Veri elde edilen yöneticilerden, kurumlarıyla ilgili olarak, işletmenin faaliyet gösterdiği sektör, çalışan personel sayısı, sermaye, ciro, bütçe vb. özellikleri taşıyan bilgiler alınmıştır. Araştırmada bilgi yönetimini ölçmek üzere Lau ve Lo (2015) tarafından geliştirilen 13 sorudan oluşan ölçek kullanılmıştır. İnovasyon yönetimini ölçmek için ise Yam ve arkadaşları (Yam vd., 2011) tarafından geliştirilen 24 soruluk ölçek kullanılmıştır.

Ana kütlede anketin uygulanması için uygun görülen kişiler; üst düzey yöneticiler olarak seçilmiştir. Böyle bir seçimin yapılma nedeni ise, üst düzey yönetici kademesinde olan kişilerin kurumlarıyla ilgili yeterli düzeyde bilgiye sahip olmalarıdır. Böylece ArGe Merkezleriyle ilgili en doğru verilere ulaşılması amaç edinilmiştir.

\section{BULGULAR}

Araştırmada elde edilen verilerin analiz edilmesinde SPSS (Statistical Package For Social Sciences) 23.0 istatistiksel paket programı kullanılarak analiz edilmiştir. Verilerin analizi esnasında, araştırmada kullanılan ölçeklerin geçerliğini test etmek için Açıklayıcı Faktör Analizi kullanılmıştır. Ölçeğin güvenirliği, Cronbach's Alpha katsayısı ile değerlendirilmiştir. Bilgi Yönetimi süreçlerinin İnovasyon Yeteneğinin alt boyutları ile olan ilişkisini sınamak için Korelasyon Analizi tercih edilmiştir. Son olarak, araştırma hipotezlerinin test edilmesinde Regresyon Analizi kullanılmıştır. Genel güvenirlik sağlamak ve güvenirliğin alt boyutların güvenirliği için Alpha katsayısı hesaplanmıştır. Sonuçlar \%95 güven aralığında, anlamlılı $p<0,05$ düzeyinde çift yönlü olarak değerlendirilmiştir.

\subsection{Faktör Analizi Bulguları (Bilgi Yönetimi Boyutları)}

KMO testi sonucu 1'e ne kadar yakınsa örneklem o denli yeterli demektir. Genellikle kabul edilen sınır bu değerin 0.5 'ten büyük olmasıdır. Çalışmamızın örneklemi için, Tabo 1'de görüldüğü üzere Bilgi Yönetimi boyutları açısından elde edilen değer 0.83 olduğundan, örneklemin faktör analizi için yeterli olduğu sonucuna varılabilir.

Tablo: 1: Bilgi Yönetimi Boyutları KMO Bartlett Testi

\begin{tabular}{lll}
\hline \multicolumn{3}{c}{ Bilgi Yönetimi KMO ve Bartlett Testi } \\
\hline Kaiser-Meyer-Olkin Ölçeği Örneklem Yeterliliği Testi & Katsayısı & 0.83 \\
& Ki-kare değeri & 281.80 \\
\hline Bartlett Küresellik Testi & $\mathrm{df}$ & 78 \\
& Sig. & 0.00 \\
\hline
\end{tabular}

Bilgi yönetimi kavramının boyutlarını test etmek üzere keşifsel faktör analizi uygulanmış ve elde edilen faktör yükleri Tablo 2'de sunulmuştur. Bulgulara göre, verilerin literatürdeki faktör yapısına uygun olduğu sonucuna varılmıştır. Faktör yüklerinin her biri $0,5^{\prime}$ in üzerinde olduğu görülmektedir. Bilgi yönetimi boyutlarının ortalamalarına bakıldığında, geri dönüş sağlayan 32 Ar-Ge Merkezinde bilgi yönetimi boyutlarının hepsinin 4'e yakın olduğu görülmektedir. Cronbach's Alpha ölçeğinin güvenirlik kat sayısının literatürde kabul edilen 0,70 'in üzerinde olduğu görülmektedir.

\section{Tablo 2: Faktör Yükleri}

\begin{tabular}{|c|c|c|c|c|}
\hline Boyutlar & & & Faktör Yükleri & \\
\hline ACQK1 & 0.71 & & & \\
\hline ACQK2 & 0.88 & & & \\
\hline ACQK3 & 0.64 & & & \\
\hline ACQK4 & 0.56 & & & \\
\hline ASSK1 & & 0.71 & & \\
\hline ASSK2 & & 0.79 & & \\
\hline TRK1 & & & 0.55 & \\
\hline TRK2 & & & 0.64 & \\
\hline TRK3 & & & 0.65 & \\
\hline EXPK1 & & & & 0.81 \\
\hline EXPK2 & & & & 0.80 \\
\hline EXPK3 & & & & 0.66 \\
\hline
\end{tabular}




\begin{tabular}{lllll} 
EXPK4 & & & 0.82 \\
\hline Ortalama & 3.76 & 3.92 & 3.87 & 3.84 \\
St.Sap & 0.95 & 0.06 & 0.10 & 0.14 \\
Cr.Alpha & 0.74 & 0.81 & 0.82 & 0.81
\end{tabular}

ACQK: Bilginin Elde Edilmesi, ASSK: Bilginin Dönüştürülmesi, TRK: Bilginin Korunması ve Paylaşılması

EXPK: Bilginin Uygulanması

\subsection{Faktör Analizi Bulguları (Inovasyon Yeteneği Boyutları)}

Örneklemimiz için İnovasyon yeteneği boyutları açısından elde edilen KMO değeri Tablo 3'de görüldüğü üzere 0.54 bulunmuş ve örneklemin faktör analizi için yeterli olduğu sonucuna varılmıştır.

Tablo 3: İnovasyon Yeteneği Boyutları KMO Bartlett Testi

\begin{tabular}{lll}
\hline \multicolumn{3}{c}{ Inovasyon Yeteneği KMO ve Bartlett Testi } \\
\hline Kaiser-Meyer-Olkin Ölçeği Örneklem Yeterliliği Testi & Katsayısı & 0.54 \\
& Ki-kare değeri & 697.22 \\
\hline Bartlett Küresellik Testi & $\mathrm{df}$ & 276 \\
& Sig. & 0.00 \\
\hline
\end{tabular}

Inovasyon yeteneği kavramının boyutlarını test etmek üzere keşifsel faktör analizi uygulanmış ve elde edilen faktör yükleri Tablo 4'de sunulmuştur. Bulgulara göre, verilerin literatürdeki faktör yapısına büyük oranda uygun olduğu görülmüş, ancak Öğrenme ve Ar-Ge yeteneği boyutları bir boyut altında birleşmiştir. İnovasyon yeteneğinin diğer boyutları kendi aralarında ayrılmıştır. Faktör yüklerinin her ikisi dışında tamamının 0,5'in üzerinde olduğu görülmektedir. Faktör yükleri 0,47 ve 0,49 olan soruların içeriği nedeniyle analizden çıkarıldıklarında ilgili faktörlerin anlamında ve kayıp olabileceği düşünüldüğünden tutulmalarına karar verilmiştir. İnovasyon yeteneği boyutlarının ortalamalarına bakıldığında, geri dönüş sağlayan 32 Ar-Ge Merkezinde boyutlarının tamamının 4'e yakın olduğu görülmektedir. Boyutlara ilişkin Cronbach's Alpha güvenirlik kat sayılarının literatürde kabul edilen 0,70 'in üzerinde olduğu görülmektedir.

\section{Tablo 4: Faktör Yükleri}

\begin{tabular}{|c|c|c|c|c|c|c|}
\hline \multirow{2}{*}{$\begin{array}{l}\text { Boyutlar } \\
\text { ÖY1 }\end{array}$} & \multicolumn{6}{|c|}{ Faktör Yükleri } \\
\hline & 0.79 & & & & & \\
\hline ÖY2 & 0.85 & & & & & \\
\hline AGY1 & 0.78 & & & & & \\
\hline AGY2 & 0.81 & & & & & \\
\hline AGY3 & 0.80 & & & & & \\
\hline KTY1 & & 0.80 & & & & \\
\hline KTY2 & & 0.83 & & & & \\
\hline КTY3 & & 0.68 & & & & \\
\hline KTY4 & & 0.65 & & & & \\
\hline ÜY1 & & & 0.69 & & & \\
\hline ÜY2 & & & 0.47 & & & \\
\hline ÜY3 & & & 0.54 & & & \\
\hline PY1 & & & & 0.67 & & \\
\hline PY2 & & & & 0.64 & & \\
\hline PY3 & & & & 0.49 & & \\
\hline PY4 & & & & 0.70 & & \\
\hline OY1 & & & & & 0.81 & \\
\hline OY2 & & & & & 0.80 & \\
\hline OY3 & & & & & 0.82 & \\
\hline SP1 & & & & & & 0.62 \\
\hline SP2 & & & & & & 0.86 \\
\hline SP3 & & & & & & 0.56 \\
\hline SP4 & & & & & & 0.54 \\
\hline SP5 & & & & & & 0.71 \\
\hline Ortalama & 3.73 & 3.68 & 3.92 & 3.81 & 3.89 & 3.82 \\
\hline St.Sap. & 0.05 & 0.22 & 0.07 & 0.14 & 0.18 & 0.16 \\
\hline
\end{tabular}


Cr.Alpha

0.93

0.77

0.79

0.71

0.86

0.77

ÖY: Öğrenme Yeteneği, AGY: Ar-Ge Yeteneği, KTY: Kaynak Tahsis Yeteneği, ÜY: Üretim Yeteneği, PY: Pazarlama Yeteneği OY: Organizasyon Yeteneği, SP: Stratejik Planlama Yeteneği

\subsection{Korelasyon Analizi Bulguları}

Aşağıdaki Tablo 5’de, Bilgi Yönetiminin alt boyutları ile İnovasyon Yeteneğinin alt boyutları arasındaki korelasyon analizi sonuçları sunulmuştur.

Tablo 5: Değişkenlere Ait Korelasyon Tablosu

\begin{tabular}{|c|c|c|c|c|c|c|c|}
\hline & & Ög_Ar_Yet & Kay_Yet & Ür_Yet & Paz_Yet & Or_Yet & St_Yet \\
\hline \multirow{3}{*}{ 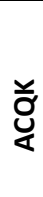 } & Pearson Correlation & ,630** & $622 * *$ &, $804 * *$ &, $805^{* *}$ &, $777^{* *}$ & ,774** \\
\hline & Sig. (2-tailed) & ,000 & ,000 & ,000 & ,000 & ,000 & ,000 \\
\hline & $\mathbf{N}$ & 32 & 32 & 32 & 32 & 32 & 32 \\
\hline \multirow{4}{*}{ 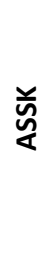 } & Pearson Correlation & ,484** & ,595** &, $618^{* *}$ & $814 * *$ &, $685^{* *}$ & ,671** \\
\hline & Sig. (2-tailed) & ,005 & ,000 & ,000 & ,000 & ,000 & ,000 \\
\hline & $\mathbf{N}$ & 32 & 32 & 32 & 32 & 32 & 32 \\
\hline & Pearson Correlation &, $525 * *$ & ,617** &, $783 * *$ &, $713 * *$ &, $813^{* *}$ & ,760** \\
\hline \multirow[t]{3}{*}{ 吕 } & Sig. (2-tailed) & ,002 & ,000 & ,000 & ,000 & ,000 & ,000 \\
\hline & $\mathbf{N}$ & 32 & 32 & 32 & 32 & 32 & 32 \\
\hline & Pearson Correlation &, $585 * *$ & ,644** & ,829** & ,793** &, $858^{* *}$ & $824 * *$ \\
\hline \multirow{2}{*}{ 亮 } & Sig. (2-tailed) & ,000 & ,000 & ,000 & ,000 & ,000 & ,000 \\
\hline & $\mathbf{N}$ & 32 & 32 & 32 & 32 & 32 & 32 \\
\hline
\end{tabular}

Tablo 5'e bakıldığında, bilginin edinilmesi değişkeninin (ACQK), tüm inovasyon yeteneği alt boyutları ile pozitif ve istatistiksel olarak anlamlı korelasyona sahip olduğu, bunlardan Üretim Yeteneği $(r=.804, p<.00)$ ve Pazarlama Yeteneği $(r=.805, p<.00)$ ile en yüksek ilişkiye sahip olduğu görülmektedir. Bilginin Dönüştürülmesi değişkeni (ASSK) de benzer şekilde tüm inovasyon yeteneği alt boyutları ile pozitif ve istatistiksel olarak anlamlı korelasyona sahiptir. Bunların arasında ise en kuvvetli olarak Pazarlama Yeteneği ile $(r=.814, p<.00)$ güçlü ve pozitif bir ilişkisi mevcuttur.

Bilginin Korunması ve Paylaşılması değişkeni (TRK) de, tüm inovasyon yeteneği alt boyutları ile istatistiksel olarak anlamlı ve pozitif bir ilişkiye sahip olmakla birlikte, en belirgin olarak Organizasyon Yeteneği ile $(r=.813, p<.00)$ kuvvetli bir ilişkisi olduğu görülmektedir. Bilginin Uygulanması değişkeni (EXPK) ise benzer şekilde tüm inovasyon yeteneği alt boyutları ile istatistiksel olarak anlamlı ve pozitif bir ilişkiye sahip olup, en kuvvetli ilişkisinin Organizasyon Yeteneği ile $(r=.858, p<.00)$ olduğu gözlemlenmektedir.

\subsection{Regresyon Analizi Bulguları}

Çalışmamızda, bilgi yönetimi boyutlarının inovasyon yeteneği boyutları üzerindeki etkilerinin belirlenmesi amacıyla, regresyon analizi gerçekleştirilmiştir. Her bir inovasyon yeteneği boyutunun ayrı ayrı bağımlı değişken olarak alındığı regresyon analizleri aşağıdaki tablolarda sunulmuştur. Aşağıdaki Tablo 6' da, Bilgi Yönetimi alt boyutlarının Öğrenme ve Ar-Ge yeteneği üzerindeki etkileri incelenmiştir. 
Tablo 6: Bilgi Yönetimi Süreçleri ile Öğrenme ve Ar-Ge Yeteneği Regresyon Sonuçları

\begin{tabular}{|c|c|c|c|c|c|c|c|c|c|c|}
\hline Modeller & & $\mathbf{R} 2$ & $\Delta \mathbf{R} \mathbf{2}$ & $\begin{array}{c}\Delta F^{\prime} \text { nin } p \\
\text { değeri }\end{array}$ & $\beta$ & $\begin{array}{l}\text { Std. } \\
\text { Hata }\end{array}$ & $\mathbf{t}$ & $\mathbf{p}$ & Tol & VIF \\
\hline \multirow[t]{6}{*}{ Model 1} & & ,407 & 407 & ,006 & & & & & & \\
\hline & Sabit & & & & ,047 & 907 & ,051 & ,959 & & \\
\hline & ACQK_ort & & & & ,728 & ,438 & 1,662 & 108 & 256 & 3,901 \\
\hline & ASSK_ort & & & & 119, & 296 & ,404 & 689 & ,405 & 2,467 \\
\hline & TRK_ort & & & & ,066 & ,406 & ,162 & ,872 & 199 & 5,037 \\
\hline & EXPK_ort & & & & ,059 & ,609 & ,097 & ,924 & ,097 & 10,318 \\
\hline \multirow[t]{5}{*}{ Model 2} & & ,407 & ,000 & ,924 & & & & & & \\
\hline & Sabit & & & & ,026 & ,865 & ,030 & 976 & & \\
\hline & ACQK_ort & & & & ,750 & ,363 & 2,065 & ,048 & 359 & 2,786 \\
\hline & ASSK_ort & & & & 133 & ,253 & ,527 & 603 & ,533 & 1,878 \\
\hline & TRK_ort & & & & ,094 & ,284 & ,330 & ,744 & ,393 & 2,542 \\
\hline \multicolumn{11}{|c|}{ Bağımlı Değişken: OY_AGY_ort } \\
\hline
\end{tabular}

Tablo 6'da verilen regresyon analizi sonuçlarına göre, Bilgi Yönetimi alt boyutları ile Öğrenme ve Ar-Ge Yeteneği arasındaki regresyon modeli anlamlıdır ( $\mathrm{R}-\mathrm{Kare}=.407 ; \Delta \mathrm{F} \mathrm{p}=.006)$. Ancak modele ait değişkenlere ilişkin katsayılar ve bunların anlamlılık değerlerine bakıldığında, hiçbir katsayının anlamlı olmadığı, ayrıca EXPK_ort değişkenine ait VIF değerinin 10'un üzerinde olduğu $(10,318)$ görülmektedir. Bu durum, bağımsız değişkenler arasında multicollinearity olduğunu göstermektedir. Model 2'de ise bu duruma sebep olan değişken (EXPK_ort) modelden atılmıştır. Yapılan analiz sonucunda Bilgi Yönetimi Alt Boyutları ile Öğrenme ve Ar-Ge Yeteneği arasındaki regresyon ilişkisi anlamlı olup atılan değişkenin neden olduğu R-Kare değişimi anlamsızdır. Diğer bir ifade ile EXPK_ort değişkenin modelden çıkarılması, modelin açıklama gücünü etkilememiştir. Regresyon analizi sonuçlarına göre $\mathrm{H} 1 \mathrm{a}$ kabul edilmiş ( $\mathrm{t}=2,065, \mathrm{p}=.048), \mathrm{H} 1 \mathrm{~b}, \mathrm{H} 1 \mathrm{c}$ ve $\mathrm{H} 1 \mathrm{~d}$ hipotezleri reddedilmiştir (sırasıyla $\mathrm{t}=.527, \mathrm{p}=.603 ; \mathrm{t}=.330, \mathrm{p}=.744 ; \mathrm{t}=.097$, $\mathrm{p}=.924)$.

Tablo 7'de Bilgi Yönetimi alt boyutları ile Pazarlama Yeteneği arasındaki regresyon ilişkisi sonuçları sunulmuştur. Verilen regresyon analizi sonuçlarına göre, Bilgi Yönetimi alt boyutları ile Pazarlama Yeteneği arasındaki ilişkiyi gösteren model anlamlıdır (R-Kare = .796; $\Delta \mathrm{F} p=.000$ ). Ancak modele ait değişkenlere ilişkin katsayılar ve bunların anlamlılık değerlerine bakıldığında, ACQK_ort ve ASSK_ort değişkenlerine ait katsayıların anlamı olduğu, diğer katsayıların anlamlı olmadığı, ayrıca EXPK_ort değişkenine ait VIF değerinin 10'un üzerinde olduğu $(10,318)$ görülmektedir. Bu durum, bağımsız değişkenler arasında multicollinearity olduğunu göstermektedir. Model 2'de ise multicollinearity durumuna sebep olan değişken (EXPK_ort) modelden atılmıştır. Yapılan analiz sonucunda Bilgi Yönetimi Alt Boyutları ile Pazarlama Yeteneği arasındaki regresyon ilişkisi anlamlı olup atılan değişkenin neden olduğu R-Kare değişimi anlamsızdır. Diğer bir ifade ile EXPK_ort değişkenin modelden çıkarılması, modelin açıklama gücünü etkilememiştir. Regresyon analizi sonuçlarına göre $\mathrm{H} 4 \mathrm{a}$ ve $\mathrm{H} 4 \mathrm{~b}$ hipotezleri kabul edilmiş (sırasıyla $t=2,855, p=.008 ; \mathrm{t}=.4,078$, $\mathrm{p}=.000$ ), $\mathrm{H} 4 \mathrm{c}$ ve H4d hipotezleri reddedilmiştir (sırasıyla $\mathrm{t}=.756, \mathrm{p}=.456 ; \mathrm{t}=.097, \mathrm{p}=.548$ ). 
Tablo 7: Bilgi Yönetimi Süreçleri ve Pazarlama Yeteneği Regresyon Sonuçları

\begin{tabular}{|c|c|c|c|c|c|c|c|c|c|c|}
\hline Modeller & & $\mathbf{R} 2$ & $\Delta \mathbf{R 2}$ & $\begin{array}{c}\Delta \mathrm{F}^{\prime} \text { nin } \mathrm{p} \\
\text { değeri }\end{array}$ & $\beta$ & $\begin{array}{l}\text { Std. } \\
\text { Hata }\end{array}$ & $\mathbf{t}$ & p & Tol & VIF \\
\hline \multirow[t]{6}{*}{ Model 1} & & ,796 & 796 & ,000 & & & & & & \\
\hline & Sabit & & & & 131 & ,372 & 351 & 728 & & \\
\hline & ACQK_ort & & & & ,487 & 180 & 2,711 & ,012 & ,256 & 3,901 \\
\hline & ASSK_ort & & & & ,462 & 121 & 3,815 & ,001 & ,405 & 2,467 \\
\hline & TRK_ort & & & & 160 & 167 & 959 & ,346 & 199 & 5,037 \\
\hline & EXPK_ort & & & &,- 152 &, 250 &,- 608 &, 548 & ,097 & 10,318 \\
\hline \multirow[t]{5}{*}{ Model 2} & &,- 152 & ,250 &,- 608 & & & & & & \\
\hline & Sabit & & & & 184 & ,357 & ,516 & 610 & 184 & \\
\hline & ACQK_ort & & & & ,428 & 150 & 2,855 & ,008 & 359 & 2,786 \\
\hline & ASSK_ort & & & & ,426 & 105 & 4,078 & ,000 & ,533 & 1,878 \\
\hline & TRK_ort & & & & ,089 & ,117 & ,756 & ,456 & ,393 & 2,542 \\
\hline $\begin{array}{l}\text { Bağımlı D } \\
\text { Analizden }\end{array}$ & $\begin{array}{l}\text { şken: PY_or } \\
\text { karılan değiş }\end{array}$ & 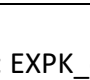 & & & & & & & & \\
\hline
\end{tabular}

Aşağıdaki Tablo 8'de verilen regresyon analizi sonuçlarına göre, Bilgi Yönetimi Alt Boyutları ile Organizasyon Yeteneği arasındaki regresyon modeli anlamlıdır (R-Kare $=.796 ; \Delta \mathrm{F} p=.000)$. Ancak modelde, hiçbir katsayının anlamlı olmadığı, ayrıca EXPK_ort değişkenine ait VIF değerinin 10 'un üzerinde olduğu $(10,318)$ görülmektedir. Bu durum, bağımsız değişkenler arasında multicollinearity olduğunu göstermektedir. Model 2'de (EXPK_ort) modelden atılmıştır. Yapılan analiz sonucunda Bilgi Yönetimi Alt Boyutları ile Organizasyon Yeteneği arasındaki regresyon ilişkisi anlamlı olup atılan değişkenin neden olduğu R-Kare değişimi anlamsızdır. Diğer bir ifade ile EXPK_ort değişkenin modelden çıkarılması, modelin açıklama gücünü etkilememiştir. Regresyon analizi sonuçlarına göre $\mathrm{H} 5 \mathrm{~b}$ kabul edilmiş ( $\mathrm{t}=.3,080, \mathrm{p}=.005), \mathrm{H} 5 \mathrm{a}, \mathrm{H} 5 \mathrm{c}$ ve H5d hipotezleri reddedilmiştir (sırasıyla $\mathrm{t}=1,596, \mathrm{p}=.122$; $t=.756, p=.456 ; t=.097, p=.193)$.

Aşağıdaki Tablo 9'da verilen regresyon analizi sonuçlarına göre, Bilgi Yönetimi Alt Boyutları ile Stratejik Planlama yeteneği arasındaki regresyon modeli anlamlıdır ( $\mathrm{R}-$ Kare $=.704 ; \Delta \mathrm{F} p=.000)$. Ancak modeldeki hiçbir katsayının anlamlı olmadığı, ayrıca EXPK_ort değişkenine ait VIF değerinin 10'un üzerinde olduğu $(10,318)$ görülmektedir. Bu durum, bağımsız değişkenler arasında multicollinearity olduğunu göstermektedir. Model 2'de ise (EXPK_ort) modelden atılmıştır. Yapılan analiz sonucunda Bilgi Yönetimi Alt Boyutları ile Stratejik Planlama Yeteneği arasındaki regresyon ilişkisi anlamlı olup atılan değişkenin neden olduğu R-Kare değişimi anlamsızdır. Diğer bir ifade ile EXPK_ort değişkenin modelden çıkarılması, modelin açıklama gücünü etkilememiştir. Regresyon analizi sonuçlarına göre H6a hipotezi kabul edilmiş (sırasıyla t=2,094, $p=.045 ; t=.2,076, p=.147$ ), H6b, H6c ve H6d hipotezleri reddedilmiştir (sırasıyla $\mathrm{t}=.1,481, \mathrm{p}=.150 ; \mathrm{t}=.2,076, \mathrm{p}=.147 ; \mathrm{t}=.197, \mathrm{p}=.279$ ).

Tablo 8: Bilgi Yönetimi Süreçleri ve Organizasyon Yeteneği Regresyon Sonuçları

\begin{tabular}{|c|c|c|c|c|c|c|c|c|c|c|}
\hline Modeller & & $\mathrm{R} 2$ & $\Delta \mathbf{R 2}$ & $\begin{array}{c}\Delta F^{\prime} \text { nin } p \\
\text { değeri }\end{array}$ & $\beta$ & $\begin{array}{l}\text { Std. } \\
\text { Hata }\end{array}$ & $\mathbf{t}$ & $\mathbf{p}$ & Tol & VIF \\
\hline \multirow[t]{5}{*}{ Model 1} & & 759 & 759 & ,000 & & & & & & \\
\hline & Sabit & & & &,- 487 &, 544 &,- 895 & 379 & & \\
\hline & ACQK_ort & & & & 205 & ,263 & ,782 & ,441 & 256 & 3,901 \\
\hline & ASSK_ort & & & & 135 & 177 & 759 & ,454 & ,405 & 2,467 \\
\hline & TRK_ort & & & & 311 & ,244 & 1,278 & 212 & 199 & 5,037 \\
\hline
\end{tabular}




\begin{tabular}{|c|c|c|c|c|c|c|c|c|c|}
\hline & \multicolumn{3}{|l|}{ EXPK ort } & \multirow[t]{2}{*}{,488 } & \multirow[t]{2}{*}{,365 } & \multirow[t]{2}{*}{1,336} & \multirow[t]{2}{*}{,193 } & \multirow[t]{2}{*}{,097 } & \multirow[t]{2}{*}{10,318} \\
\hline \multirow[t]{5}{*}{ Model 2} & ,743 &,- 016 & 193 & & & & & & \\
\hline & Sabit & & &,- 660 & ,536 & $-, 1,231$ & ,229 &,- 660 & \\
\hline & ACQK_ort & & & ,250 & 157 & 1,596 & ,122 & ,533 & 1,878 \\
\hline & ASSK_ort & & & ,541 & 176 & 3,080 & ,005 & ,393 & 2,542 \\
\hline & TRK_ort & & & ,089 & 117 & ,756 & ,456 & ,393 & 2,542 \\
\hline
\end{tabular}

Tablo 9: Bilgi Yönetimi Süreçleri ve Stratejik Planlama Yeteneği Regresyon Sonuçları

\begin{tabular}{|c|c|c|c|c|c|c|c|c|c|c|}
\hline Modeller & & $\mathbf{R} 2$ & $\Delta \mathbf{R 2}$ & $\begin{array}{c}\Delta F^{\prime} \text { nin p } \\
\text { değeri }\end{array}$ & $\beta$ & $\begin{array}{l}\text { Std. } \\
\text { Hata }\end{array}$ & $\mathbf{t}$ & $p$ & Tol & VIF \\
\hline \multirow[t]{6}{*}{ Model 1} & & ,704 & 704 & ,000 & & & & & & \\
\hline & Sabit & & & & 680 & ,437 & 1,555 & 132 & & \\
\hline & ACQK_ort & & & & 250 & 211 & 1,186 & 246 & ,256 & 3,901 \\
\hline & ASSK_ort & & & & 108 & 142 & 757 & 456 & ,405 & 2,467 \\
\hline & TRK_ort & & & & 138 & 196 & 703 & ,488 & 199 & 5,037 \\
\hline & EXPK_ort & & & & 324 & 293 & 1,105 & 279 & 197 & 10,318 \\
\hline \multirow[t]{5}{*}{ Model 2} & & 691 &,- 013 & ,279 & & & & & & \\
\hline & Sabit & & & & ,565 & ,426 & 1,325 & 196 & ,565 & \\
\hline & ACQK_ort & & & & 375 & 179 & 2,094 & ,045 & 359 & 2,786 \\
\hline & ASSK_ort & & & & 185 & 125 & 1,481 & 150 & ,533 & 1,878 \\
\hline & TRK_ort & & & & 290 & 140 & 2,076 & 147 & 393 & 2,542 \\
\hline $\begin{array}{l}\text { Bağımlı De } \\
\text { Analizden }\end{array}$ & $\begin{array}{l}\text { en: SP_or } \\
\text { Illan değiş }\end{array}$ & & & & & & & & & \\
\hline
\end{tabular}

Gerçekleştirilen regresyon analiz sonuçlarına göre elde edilen bulgulara ilişkin olarak, ortaya konulan hipotezlerin kabul ve red durumlarını özetleyen Tablo 10 aşağıda sunulmuştur.

Tablo 10: Araştırma Hipotezleri'nin Kabul ve Ret Durumları

\begin{tabular}{llc}
\hline Hipotez & Açıklama & Durum \\
\hline H1a & $\begin{array}{l}\text { Bilginin edinilmesi sürecinin işletmenin Öğrenme ve Ar-Ge Yeteneği üzerinde olumlu bir } \\
\text { etkisi vardır. }\end{array}$ & Kabul \\
\hline H1b & $\begin{array}{l}\text { Bilginin dönüştürülmesi sürecinin işletmenin Öğrenme ve Ar-Ge Yeteneği üzerinde } \\
\text { olumlu bir etkisi vardır. }\end{array}$ & Red \\
\hline H1c & $\begin{array}{l}\text { Bilginin korunması ve paylaşılması sürecinin işletmenin Öğrenme ve Ar-Ge Yeteneği } \\
\text { üzerinde olumlu bir etkisi vardır. }\end{array}$ & Red \\
\hline
\end{tabular}




\begin{tabular}{|c|c|c|}
\hline $\mathrm{H} 1 \mathrm{~d}$ & $\begin{array}{l}\text { Bilginin uygulanması sürecinin işletmenin Öğrenme ve Ar-Ge Yeteneği üzerinde olumlu } \\
\text { bir etkisi vardır. }\end{array}$ & Red \\
\hline $\mathrm{H} 2 \mathrm{a}$ & $\begin{array}{l}\text { Bilginin edinilmesi sürecinin işletmenin Kaynak Tahsisi Yeteneği üzerinde olumlu bir } \\
\text { etkisi vardır. }\end{array}$ & Red \\
\hline $\mathrm{H} 2 \mathrm{~b}$ & $\begin{array}{l}\text { Bilginin dönüştürülmesi sürecinin işletmenin Kaynak Tahsisi Yeteneği üzerinde olumlu } \\
\text { bir etkisi vardır. }\end{array}$ & Red \\
\hline $\mathrm{H} 2 \mathrm{c}$ & $\begin{array}{l}\text { Bilginin korunması ve paylaşılması sürecinin işletmenin Kaynak Tahsisi Yeteneği } \\
\text { üzerinde olumlu bir etkisi vardır. }\end{array}$ & Red \\
\hline $\mathrm{H} 2 \mathrm{~d}$ & $\begin{array}{l}\text { Bilginin uygulanması sürecinin işletmenin Kaynak Tahsisi Yeteneği üzerinde olumlu bir } \\
\text { etkisi vardır. }\end{array}$ & Red \\
\hline $\mathrm{H} 3 \mathrm{a}$ & $\begin{array}{l}\text { Bilginin edinilmesi sürecinin işletmenin Üretim Yeteneği üzerinde olumlu bir etkisi } \\
\text { vardır. }\end{array}$ & Kabul \\
\hline $\mathrm{H} 3 \mathrm{~b}$ & $\begin{array}{l}\text { Bilginin dönüştürülmesi sürecinin işletmenin Üretim Yeteneği üzerinde olumlu bir etkisi } \\
\text { vardır. }\end{array}$ & Red \\
\hline $\mathrm{H} 3 \mathrm{c}$ & $\begin{array}{l}\text { Bilginin korunması ve paylaşılması sürecinin işletmenin Üretim Yeteneği üzerinde } \\
\text { olumlu bir etkisi vardır. }\end{array}$ & Kabul \\
\hline $\mathrm{H} 3 \mathrm{~d}$ & $\begin{array}{l}\text { Bilginin uygulanması sürecinin işletmenin Üretim Yeteneği üzerinde olumlu bir etkisi } \\
\text { vardır. }\end{array}$ & Red \\
\hline $\mathrm{H} 4 \mathrm{a}$ & $\begin{array}{l}\text { Bilginin edinilmesi sürecinin işletmenin Pazarlama Yeteneği üzerinde olumlu bir etkisi } \\
\text { vardır. }\end{array}$ & Kabul \\
\hline $\mathrm{H} 4 \mathrm{~b}$ & $\begin{array}{l}\text { Bilginin dönüştürülmesi sürecinin işletmenin Pazarlama Yeteneği üzerinde olumlu bir } \\
\text { etkisi vardır. }\end{array}$ & Kabul \\
\hline $\mathrm{H} 4 \mathrm{c}$ & $\begin{array}{l}\text { Bilginin korunması ve paylaşılması sürecinin işletmenin Pazarlama Yeteneği üzerinde } \\
\text { olumlu bir etkisi vardır. }\end{array}$ & Red \\
\hline $\mathrm{H} 4 \mathrm{~d}$ & $\begin{array}{l}\text { Bilginin uygulanması sürecinin işletmenin Pazarlama Yeteneği üzerinde olumlu bir etkisi } \\
\text { vardır. }\end{array}$ & Red \\
\hline $\mathrm{H} 5 \mathrm{a}$ & $\begin{array}{l}\text { Bilginin edinilmesi sürecinin işletmenin Organizasyon Yeteneği üzerinde olumlu bir etkisi } \\
\text { vardır. }\end{array}$ & Red \\
\hline $\mathrm{H} 5 \mathrm{~b}$ & $\begin{array}{l}\text { Bilginin dönüştürülmesi sürecinin işletmenin Organizasyon Yeteneği üzerinde olumlu bir } \\
\text { etkisi vardır. }\end{array}$ & Kabul \\
\hline $\mathrm{H} 5 \mathrm{c}$ & $\begin{array}{l}\text { Bilginin Korunması Ve Paylaşılması sürecinin işletmenin organizasyon yeteneği üzerinde } \\
\text { olumlu bir etkisi vardır. }\end{array}$ & Red \\
\hline $\mathrm{H} 5 \mathrm{~d}$ & $\begin{array}{l}\text { Bilginin Uygulanması sürecinin işletmenin organizasyon yeteneği üzerinde olumlu bir } \\
\text { etkisi vardır. }\end{array}$ & Red \\
\hline $\mathrm{H6a}$ & $\begin{array}{l}\text { Bilginin Edinilmesi sürecinin işletmenin stratejik planlama yeteneği üzerinde olumlu bir } \\
\text { etkisi vardır. }\end{array}$ & Kabul \\
\hline
\end{tabular}

\section{SONUÇ VE ÖNERILER}

Bu araştırma kapsamında yapılan uygulamalı çalışmayla, Doğu Marmara Bölgesindeki Ar-Ge Merkezleri ele alınarak, Bilgi Yönetimi ve İnovasyon Yeteneği kavramları arasındaki ilişki ampirik olarak incelenmiştir. Ar-Ge Merkezleri, inovasyonun oluşturulmasında fikrin faaliyete geçmesi ve işletmelerin inovasyon yeteneklerini geliştirebilmelerine, aynı zamanda da araştırılan ve toplanan bilgilerin kullanılabilmesine fırsatlar sunan, teknoloji kullanımına ve ekonomik yatırıma dayanan merkezler olarak ortaya çıkmakta, ülke ekonomisine yön veren ve sanayi faaliyetlerini destekleyen kilit bir rol oynamaktadırlar (Tripsas vd., 1995).

Bilgi yönetimi, işletmelerin elde ettikleri verileri pratik ve hızlı olarak kullanabilmelerini sağlayan, değişen çevre şartlarına zorlanmadan odaklanılmasında önemli rol oynayan, karar alma süreçlerini kolaylaştıran, sürdürülebilir bir rekabetçilik elde edilmesinde, organizasyonel yapının iyileştirilmesi ve faaliyetlerin kontrolünün sağlanmasında etkisi olan çok önemli bir süreç olarak karşımıza çıkmaktadır. Bilgi yönetimi, teknolojinin kullanılmasını, finansal değerlerin belirlenmesini, rakip işletmelerle olan rekabet gücünü kontrol etmeyi, yetenekli ve bilgili ve donanımlı, deneyimli, bilginin işlevsel olarak yürütülmesi ve sürdürülmesine destek olan bir süreçtir (Alavi ve Leidner, 2001). Bu bağlamda, özellikle bilgiyi en önemli kaynak olarak ele alan Ar-Ge merkezlerinde, bilginin yönetilmesine ilişkin boyutların, bu merkezlerin inovasyon oluşturma ve yönetme yetenekleri üzerinde ne gibi bir etkisinin olduğu, önemli bir soru ve araştırma alanı olarak ortaya çıkmaktadır.

Ar-Ge Merkezlerinin organizasyonların ve sektörlerin gelişmesinde oynadıkları rolde bilgi yönetiminin etkili olduğu ve bilginin etkin ve verimli kullanılmasının ise inovasyon yeteneğinin ortaya çıkarılmasında ve yönetilmesinde avantajlar oluşturduğu, literatürde gerçekleştirilmiş çalışmalara da dayanarak öne sürülmüş ve çalışma kapsamında ele alınmıştır. Çalışmamızın ana hatlarından biri 
olan inovasyon yeteneği ise; inovasyon çerçevesinde hareket eden yenilikçiliği kapsayan; yenilik kapsamı çerçevesinde farklı olan, yeniden oluşturulan değerler, dönüştürülen ürünler ve süreçlerin ilerlemesinde etkili olan teknik ve metotlar olarak genellenebilmektedir (Ertürk, 2012).

Bu çalışma, ülkemizin gelişme, kalkınma ve büyümesinde çok önemli bir rol oynayan, TÜBiTAK ve birçok Teknopark dahil olmak üzere sanayi ve teknoloji kuruluşlarına ve firmalarına ev sahipliği yapan Doğu Marmara Bölgesinde (TR42) faaliyet gösteren Ar-Ge Merkezleri'nde gerçekleştirilmiş, bu merkezlerde bilgi yönetiminin inovasyon yeteneği ile olan ilişkisi araştırılmıştır. Bu araştırma kapsamında, Bilgi yönetimi; Bilginin Elde Edilmesi, Bilginin Dönüştürülmesi, Bilginin Korunması ve Paylaşılması, Bilginin Uygulanması olmak üzere dört boyutta ele alınmıştır. İnovasyon yeteneği ise, Öğrenme Yeteneği ve Ar-Ge Yeteneği, Kaynak Tahsis Yeteneği, Üretim Yeteneği, Pazarlama Yeteneği, Organizasyon Yeteneği, Stratejik Planlama Yeteneği olarak altı boyutta tanımlanmıştır.

Bu araştırmanın uygulama kısmında nicel araştırma yöntemleri benimsenmiş, bu nedenle bilgi yönetimi ve inovasyon yeteneği boyutları, literatürde tespit edilen, geçerlilik ve güvenilirlikleri birçok araştırma ile kanıtlanmış ölçekler kullanılarak ölçülmüştür. Araştırmanın evreni olarak ise, Doğu Marmara Bölgesi'nde faaliyet gösteren tüm Ar-Ge Merkezleri olarak belirlenmiş, örneklem ise tam sayın yöntemiyle tüm Ar-Ge merkezlerini kapsamıştır. Süreç içerisinde tüm merkezlerin yöneticileri ile iletişim kurulmasına rağmen, çalışmaya 32 merkezin yöneticileri katılmış ve bilgi sağlamışlardır.

Çalışmada elde edilen veriler üzerinde yapılan analizler neticesinde şu sonuçlar elde edilmiştir:

- Bilgi yönetiminin alt boyutlarından olan bilginin edinilmesinin, Ar-Ge Merkezlerinin inovasyon yeteneği alt boyutlarını en fazla etkilediği görülmektedir. İnovasyon yeteneği, süreç olarak bilgiye dayalı olarak yürütülen ve yönetilen bir süreçtir. Bu bağlamda, elde edilen bilginin kalitesi, erişilebilirliği, güvenilirliği, doğruluğu ve güncelliği, özellikle yeni bir alanda araştırma ve geliştirme gibi bilgi yoğun bir faaliyet yürütmekte olan bu merkezlerin tüm süreçlerini etkilemesi kaçınılmazdır. Bilgi yönetiminin diğer aşamalarının başarısı da, bilginin edinilmesi aşamasının ne derece başarılı olacağına bağlıdır. Benzer şekilde, inovasyon yeteneğinin boyutlarının etkinliği de, kullanılacak bilginin ne derece doğru ve etkin şekilde toplanmasına bağlı olacaktır. Bilginin edinilmesi aşamasının, özellikle Ar-Ge merkezlerinin inovasyon yeteneği üzerinde en fazla etkiye sahip alan olarak ortaya çıkması, bilgi yönetiminin ve inovasyon yeteneğinin diğer tüm süreçlerinin de temelini oluşturan bu aşamanın önemini bir kez daha göstermektedir.

- Analiz sonuçlarına göre, bilgi yönetiminin alt boyutlarından olan bilginin korunması ve paylaşılması Ar-Ge Merkezlerinin inovasyon yeteneği alt boyutlarından sadece üretim yeteneğini olumlu etkilediği diğer yetenekler üzerinde herhangi bir olumlu etkisi görülmemektedir. Bilginin paylaşılması, teorik anlamda inovasyon yeteneğinin tüm alt boyutlarını etkileyen bir aşamadır. Ancak, bu çalışmada ele alınan inovasyon boyutlarından üretim yeteneğinin temelinde, bilginin paylaşılarak üretim aşamalarına aktarılması yer almaktadır. Bu anlamda, bilginin paylaşılması boyutunun en fazla oranda üretim yeteneğini anlamlı bir şekilde etkilemesi, Ar-Ge merkezleri üretim aşamasında bilginin paylaşılmasının kritik rolünü vurgulayan bir sonuç olmuştur.

- Analiz sonuçlarına göre, bilgi yönetim sürecinin hiçbir alt boyutunun kaynak tahsis yeteneği üzerinde anlamlı ve olumlu bir etkisi olmadığı tespit edilmiştir. Kaynak tahsis yeteneği, bu çalışmada "bilginin işlenmesi için firmaların teminini gerçekleştirdiği bilgi, hammadde, teknoloji finansal değerlerle ve iş gücü gibi donanımın temin edilmesidir" olarak tanımlanmaktadır. Bu tanımda da görüleceği gibi, bu yetenek aynı zamanda bilgi yönetimi sürecinin başlangıcından önce yapılması gereken donanımın temin edilmesi aşamasını içermektedir. Bu çerçevede, örneklemde yer alan Ar-Ge merkezleri için, kaynak tahsisi bilgi yönetimi süreçlerinin başlangıcından önce gerçekleştirilen bir boyut olarak algılandığı, ve bu nedenle böyle bir sonucun ortaya çıkmış olabileceği değerlendirilmektedir.

Çalışmamızın her ne kadar amacına ulaştığı ve Ar-Ge merkezleri açısından önemli sonuçlar ortaya koyduğu düşünülse de, çalışma sürecinde karşılaşılan kısıtların vurgulanması gerekmektedir. Bu bağlamda öne çıkan hususlar ve bunlara ilişkin öneriler ise şu şekilde sıralanabilir:

- Bu çalışmada sadece, daha önce ifade edilen öneminden ve ülke ekonomisi üzerindeki rolünden dolayı Doğu Marmara bölgesi üzerinde durulmuş, zaman ve maliyet yetersizliğinden dolayı araştırma alanı genişletilememiştir. Bu çalışma kapsamında yer alan hipotezler sadece Doğu Marmara Bölgesindeki Ar-Ge Merkezlerinde değil Türkiye'deki bütün ArGe Merkezleri ele alınarak gerçekleştirildiğinde, daha anlamlı sonuçların elde edilebileceği ve çalışmanın bulgularının genişletilebileceği değerlendirilmektedir.

- Araştırma alanı sadece firmaların Ar-Ge Merkezlerini kapsamaktadır. Teknoparklar ve üniversitelerin Ar-Ge Merkezlerinnin de bu araştırma dahil edilmesi, sonuçların geçerliliğini artıracaktır. 
- Çalışmada her ne kadar bilgi yönetiminin inovasyon yeteneği üzerindeki muhtemel etkisi incelense de, gelecekte yapılacak çalışmalarda bu ilişki üzerinde etkisi olabilecek aracı ve düzenleyici değişkenlere de yer verilerek, daha kapsamlı ve bütüncül modeller kullanılabilir.

\section{KAYNAKÇA}

Alavi, M. \& Leidner, D. E. (2001). Knowledge management and knowledge management systems: Conceptual foundations and research issues, MIS Quarterly, 25(1), 107-136.

Biloslavo, R., Kljajić-Dervić, M. \& Dervić, Š. (2018). Factors affecting effectiveness of knowledge management: A case of Bosnia and Herzegovina trade enterprises, Knowledge Process Management, 1-12.

Calantone, R.J., Cavusgil, S.T., \& Zhao, Y. (2002). Learning orientation, firm innovation capability, and firm performance, Industrial Marketing Management, 31, 515-524.

Camisón, C. \& Forés, B. (2010). Knowledge absorptive capacity: New insights for its conceptualization and measurement, Journal of Business Research, 63, 707-715.

Colombo, M.G. \& Garrone, P. (1996). Technological cooperative agreements and firm's R\&D intensity: A note on causative relations, Research Policy, 25, 923-932.

Elçi, Ş. (2007). Inovasyon: Kalkınma ve Rekabetin Anahtarı (2. Basım). İstanbul: Nova Yayınları.

Ertürk, A. (2012). Linking psychological empowerment to innovation capability: Investigating the moderating effect of supervisory trust, International Journal of Business and Social Science, 3(14), 153-165.

Flatten, T. C., Engelen, A., Zahra, S. A. \& Brettel, M. (2011). A measure of absorptive capacity: Scale development and validation, European Management Journal, 29, 98-116.

Fugate, B. S., Stank, T. P. \& Mentzer, J.T. (2009). Linking improved knowledge management to operational and organizational performance, Journal of Operational Management, 27, 247-264.

Grant, R. M. (1996). Toward a knowledge-based theory of the firm, Strategic Management Journal, 17, 109-122.

Gupta, B., Lyer, L. S. \& Aronson, J. E. (2000). Knowledge management: Practices and challenges, Industrial Management \& Data Systems, 10(1), $17-21$.

Hervas-Oliver, J. L., Garrigos, J. A. \& Gil-Pechuan, I. (2011). Making sense of innovation by R\&D and Non-R\&D innovators in low technology contexts: A forgotten lesson for policymarkers, Technovation, 31, 427-446.

Hsu, Y. H. \& Fang, W. (2009). Intellectual capital and new product development performance: The mediating role of organizational learning capability, Technological Forecasting \& Social Change, 76, 664-677.

Ishak, I.S., Abu Hassan R., Alias, R. A., Basaruddin, S. \& Surasi, Z. (2013). The status of innovation value chain in one of Malaysia public research institutes and government agencies, Paper presented at the International Conference on Research and Innovation in Information Systems.

Jansen, J. J. P., Van Den Bosch., F. A. J. \& Volberda, H. W. (2005). Managing potential and realized absorptive capacity: How do organizational antecedents matter? Academy of Management Journal, 48, 999-1015.

Knockaert, M., Spithoven, A. \& Clarysse, B. (2014). The impact of technology intermediaries on firm cognitive capacity additionality, Technological Forecasting \& Social Change, 81, 376-787.

Korkmaz, S., Ermeç, A. \& Yücedağ, N. (2009). İşletmelerin yenilikçi kabiliyetleri ve ihracat performanslarına etkileri, Anadolu Üniversitesi Sosyal Bilimler Dergisi, 9(2), 83-104.

Kostopoulos, K., Papalexandris, A., Papachroni, M. \& loannou, G. (2011). Absorptive capacity, innovation, and financial performance, Journal of Business Research, 64, 1335-1343.

Lane, P. J., Koka, B. R. \& Pathak, S. (2006). The verification of absorptive capacity: A critical review and rejuvenation of the construct, Academy of Management Review, 31 (4), 833-863.

Lau, A.K.W. \& Lo, W. (2015). Regional innovation system, absorptive capacity and innovation performance: An empirical study, Technological Forecasting \& Social Change, 92, 99-114.

Lee, H. S. \& Suh, Y. H. (2003), Knowledge conversion with information technology of Korean companies, Business Process Management Journal, 9(3), 317-336.

$\mathrm{Li}, \mathrm{X}$. (2011). Sources of external technology, absorptive capacity and Innovation capability in Chinese state-owned high-tech enterprises, World Development, 39 (7), 1240-1248. 
Maravelakis, E., Bilalis, N., Antoniadis, A., Jones, K. A. \& Moustakis, V. (2006). Measuring and benchmarking the innovativeness of SMEs: A threedimensional fuzzy logic approach, Production Planning \& Control: The Management of Operations, 17(3), 283-292.

Narasimhan, O., Rajiv, S. \& Dutta, S. (2006). Absorptive capacity in high-technology market: The competitive advantage of the haves, Marketing Science, $25(5), 510-524$.

Nemanich, L. A., Keller, R. T., Vera, D. \& Chin, W. W. (2010). Absorptive capacity in R\&D project teams: A conceptualization and empirical test, IEEE Transactions on Engineering Management, 57 (4), 674-688.

Rosenbusch, N., Brinckmann, J. \& Bausch, A. (2011). Is innovation always beneficial? A meta-analysis of the relationship between innovation and performance in SMEs, Journal of Business Venturing, 26, 441-457.

Rothaermel, F. T. \& Alexandre, M. T. (2009). Ambidexterity in technology sourcing: The moderating role of absorptive capacity, Organization Science, 20 (4), 759-780.

Rubenstein-Montano, B., Liebowitz, J., Buchwalter, J., Mccaw, D., Newman, B. \& Rebeck, K. (2001). A systems thinking framework for knowledge management, Decision Support Systems, 31, 5-16.

Tidd, J., Bessant, J. \& Pavitt, K. (2005). Managing Innovation: Integrating Technological, Market and Organizational Change, Third Edition.

Todorova, G. \& Durisin, B. (2007). Absorptive capacity: Valuing a reconceptualization, Academy of Management Review, 32(3), 774-786.

Tripsas, M., Schrader, S. \& Sobrero, M. (1995). Discouraging opportunistic behavior in collaborative R\&D: A new role for government, Research Policy, 24, 367-389.

Vila, N. \& Kuster, I. (2007). The importance of international textile firms, European Journal of Marketing, 41(1/2), 17-36.

Wang, C. \& Han, Y. (2011). Linking properties of knowledge with innovation performance: The moderate role of absorptive capacity, Journal of Knowledge Management, 1(5), 802-819.

Xia, T. \& Roper, S. (2008). Form capability to connectivity-absorptive capacity and exploratory alliances in biopharmaceutical firms: A US-Europe comparison, Technovation, 28, 776-785.

Yam, R. C. M., Lo, W., Tang, E. P. Y. \& Lau, A. K. W. (2011). Analysis of sources of innovation, technological innovation capabilities, and performance: An empirical study of Hong Kong manufacturing industries, Research Policy, 40, 391-402.

Zahra, S.A., \& George, G. (2002). Absorptive capacity: A review, reconceptualization and extension, Academy of Management Review, 27 (2), 185203. 